(c) American Dairy Science Association, 2002.

\title{
Forage Intake, Meal Patterns, and Milk Production of Lactating Dairy Cows Fed Grass Silage or Pea-Wheat Bi-Crop Silages
}

\author{
M. B. Salawu, ${ }^{*, 1}$ A. T. Adesogan, ${ }^{\star, 2}$ \\ and R. J. Dewhurst $†$ \\ *Institute of Rural Studies, \\ University of Wales, Aberystwyth SY23 3AL, United Kingdom \\ †Institute of Grassland and Environmental Research, \\ Plas Gogerddan, Aberystwyth SY23 3EB, United Kingdom
}

\section{ABSTRACT}

This study investigated the feed intake, milk production, and plasma nutrient status in dairy cows fed intercropped pea-wheat (bi-crop) silages comprised of contrasting ratios of pea to wheat. Spring peas (cv. Magnus) and wheat (cv. Axona) sown at either high (75:25) or low (25:75) pea inclusion rates were harvested after 13 (Cut 1) or 15 (Cut 2) wk. Eighteen Holstein-Friesian cows between wk 9 and 10 of lactation were used in a cyclical changeover design with three 28 -d periods. Cows were fed the bi-crop silages and $6 \mathrm{~kg}$ of concentrates or second-cut grass silage supplemented with 6 (GS6) or 9 (GS9) kg/d of concentrates. Forage intakes were higher when bi-crops were fed (10.3 to $11.4 \mathrm{~kg}$ dry matter $[\mathrm{DM}] / \mathrm{d})$ than when grass silage was fed $(8.6 \mathrm{~kg}$ $\mathrm{DM} / \mathrm{d}$ ). Total DM intake was similar among cows fed the bi-crop silages and GS9 diets, but intakes for GS6 were at least $1.7 \mathrm{~kg} \mathrm{DM} / \mathrm{d}$ lower. Increasing the pea inclusion rate increased the crude protein (CP) content of the ration, but it did not enhance forage quality or animal performance. The rate of intake of the different forages was similar, so that the higher intakes of bicrop silages were associated with more time spent at the feedbunk and an increased number of meals. Diet digestibility ranged from 531 to $650 \mathrm{~g} / \mathrm{kg}$, and the highest value was given by the Cut 1 bi-crop silage diet. Milk yield tended to be similar for cows fed the Cut 2 bi-crop and GS9 diets, and these values were at least 1.7 $\mathrm{kg}$ higher than those for cows fed on other treatments. Generally, the bi-crop diets resulted in higher milk fat contents and lower polyunsaturated fatty acid contents.

\footnotetext{
Received March 5, 2002.

Accepted May 6, 2002.

Corresponding author: A. T. Adesogan; e-mail: adesogan@ animal.ufl.edu.

${ }^{1}$ Current address: Commonwork Farms Ltd., Bore Place, Chiddingstone, Kent TN8 7AR, United Kingdom.

${ }^{2}$ Current address: Department of Animal Sciences, University of Florida, PO Box 110910, Gainesville, Florida 32611.
}

Milk protein content was highest for cows fed the GS9 diet. Blood metabolite content was unaffected by treatment except for blood urea nitrogen content, which was higher in cows fed the bi-crop silages, reflecting reduced $\mathrm{N}$-use efficiency with these diets. The study showed that pea-wheat bi-crop silages can be used to replace moderate-quality grass silage in dairy cow rations, but their role as alternatives to high-quality forages requires additional investigation.

(Key words: legume cereal intercrop, legume silage, meal patterns, milk production)

Abbreviation key: GS = grass silage, GS6 = grass silage supplemented with $6 \mathrm{~kg}$ of concentrate, GS9 = grass silage supplemented with $9 \mathrm{~kg}$ of concentrate, $\mathbf{H P}$ = high-pea bi-crop, HP1 = high-pea bi-crop (Cut 1), HP2 = high-pea bi-crop (Cut 2), LP = low-pea bi-crop, LP1 = low pea bi-crop (Cut 1), LP2 = low-pea bi-crop (Cut 2).

\section{INTRODUCTION}

Dairy farming in northwestern Europe has increasingly become dependent on grass silage-based rations for winter feeding. The relatively slow rate of fermentation of grass silage in the rumen and high concentrations of quickly degraded $\mathrm{N}$ mean that these rations tend to promote relatively low DMI and poor N utilization (Dewhurst et al., 1996). A number of studies have investigated the use of fermented or alkali-treated whole-crop cereals in dairy cow diets to overcome these problems. Although diets based on whole-crop cereals usually increased the utilization of dietary $\mathrm{N}$ and increased DMI, they were only moderately digestible and resulted in marginal improvements in milk production (Phipps et al., 1995).

The high rates of intake, ruminal fermentation, and ruminal passage of legumes are already recognized (Waghorn et al., 1989; Mustafa et al., 2000) and may complement the relatively rapid ruminal degradation characteristics of wheat silages. Interest in cereal-legume intercrops for winter-feeding has grown in Brit- 
ain, where farmers are seeking for cheaper, non-animal-based and traceable (source-verified) ration ingredients that will improve the efficiency of their production systems. Previous work has shown that peawheat bi-crop silages are high-yielding, environmentally benign forages that promote higher DMI and greater nitrogen retention when compared to sheep fed with grass silages (Adesogan et al., 2002; Salawu et al., 2001a). In addition, their appreciable contents of readily degradable starch and protein (Adesogan, Salawu, and Dewhurst, unpublished data) suggest enhanced microbial protein production, further contributing to their potential to replace purchased concentrates in rations.

The objective of this study was to determine feed intake and milk production from dairy cows offered grass silage or four pea-wheat bi-crop silages contrasting in pea-to-wheat ratio and maturity. Forage feeding behavior was analyzed to understand the basis of any observed differences in intake. The forages were supplemented with $6 \mathrm{~kg} / \mathrm{d}$ of concentrates and compared with an additional treatment comprising grass silage and $9 \mathrm{~kg} / \mathrm{d}$ of concentrate to evaluate the concentrate sparing effect of the bi-crop silages.

\section{MATERIALS AND METHODS}

\section{Crop Details}

The bi-crop silages were produced from intercropped spring varieties of pea (Pisum sativum var. Magnus) and wheat (Triticum aestivum var. Axona) on a fertilized (50 kg/ha phosphate + potash; 0:24:24), 10-ha field near Aberystwyth, Wales, UK $\left(52^{\circ} \mathrm{N}, 4^{\circ} \mathrm{W}\right)$. The Magnus pea is a long-straw variety, whereas the Axona wheat is a short-straw variety. The average annual rainfall of the area is $117 \mathrm{~cm}$, and the soil was a gleyed siltyclay loam. The bi-crops were established using a precision drill (Nordsten NS1030; Gyroveg, Skive, Denmark) at target pea-to-wheat ratios of 75:25 (high peas [HP]) and 25:75 (low peas [LP]), respectively, between May 11 and 13,1998 . The actual seed rates used were 230 and $32 \mathrm{~kg} / \mathrm{ha}$, respectively, of peas and wheat for the HP treatment, and 134 and $63 \mathrm{~kg} / \mathrm{ha}$, respectively, for the LP treatment. A pre-emergence herbicide (Paraquat [Gramoxone] Kings Langley, Hertfordshire, UK) was applied at $3.0 \mathrm{~L} / \mathrm{ha}$ on March 17, 1998, and a postemergence herbicide for broad-leaf weed control (Tropotox MCPB; Rhone Poulenc Agrochimie, Lyon, France) was applied at $5.6 \mathrm{~L} /$ ha on June 4, 1998.

The bi-crops were harvested at 13 (Cut 1) and 15 (Cut 2) wk after sowing, when the mean DM contents were $30.1 \%$ (Cut 1) or $33.3 \%$ (Cut 2). The growth stages of the peas and wheat at Cut 1 were the full pod and the early milk stage, respectively, and the corresponding stages at Cut 2 were the yellow wrinkled pods and the late milk-to-early dough stage, respectively (Zadoks et al., 1974). Cutting was accomplished with a disc mower fitted with a conditioner, and the bi-crops were wilted overnight before being picked up with a precision-chop forage harvester (mean chop length $=22 \mathrm{~mm}$ ). An inoculant additive containing lactic acid bacteria (Lactobacillus buchneri; $10^{5} \mathrm{cfu} / \mathrm{g}$ fresh weight) and cell wall degrading enzymes (Biotal Ltd., Cardiff, UK) was applied at harvest to ensure the aerobic stability of the bi-crop silages. The bi-crop silages were conserved in 40-tonne bunker silos with concrete walls.

The control grass silage (GS) was made from a second-cut, perennial ryegrass sward (Lolium perenne L.). The ryegrass was also harvested and precision chopped with a forage harvester (mean chop length $=20 \mathrm{~mm}$ ), but it was conserved without wilting or additive application in 40-tonne concrete-walled bunker silos.

\section{Cows and Their Management}

Eighteen multiparous Holstein-Friesian cows weighing $587 \mathrm{~kg}(\mathrm{SD}=52.3)$ were selected for this research. The cows were between their ninth and tenth wk of lactation at the start of the experiment and were housed in a free-stall barn and bedded on wood shavings. They had continuous access to clean drinking water and ad libitum access to the feeds through Roughage Intake Control feeders (Insentec B.V., Markensee, The Netherlands). Cows were given $8 \mathrm{~kg} / \mathrm{d}$ (as-is basis) of the standard concentrate and grass silage for ad libitum consumption before the commencement of the experiment, and covariance measurements of DMI and milk production were made in the week before dietary treatments were introduced.

Six dietary treatments were evaluated: the five forages were each supplemented with $6 \mathrm{~kg} / \mathrm{d}$ (as-is basis) of standard concentrate (Table 1) to give treatments, high-pea bi-crop, Cut 1 (HP1), high-pea bi-crop, Cut 2 (HP2), low-pea bi-crop, Cut 1 (LP1), low-pea bi-crop, Cut 2 (LP2), and grass silage supplemented with $6 \mathrm{~kg}$ of concentrate (GS6). A sixth treatment was comprised of grass silage and $9 \mathrm{~kg} / \mathrm{d}$ (as-is basis) of the standard concentrate. This treatment was included to test the ability of pea-wheat bi-crop silages to replace concentrates in grass-silage-based rations. The cows received $2 \mathrm{~kg} / \mathrm{d}$ of concentrates at each of two milking times $(0600$ and $1600 \mathrm{~h}$ ), and the remaining concentrate allocation through out-of-parlor feeders. Fresh silage was given daily each morning (between 0730 and $1030 \mathrm{~h}$ ). The cows were allocated to the six treatments in a cyclical changeover design (Davis and Hall, 1969) with three 28-d periods. 
Table 1. Ingredient composition (\%, as mixed) and chemical analysis (\% of DM, unless stated otherwise) of the concentrate.

\begin{tabular}{|c|c|}
\hline Item & Composition \\
\hline $\begin{array}{l}\text { Feedstuff } \\
\text { Wheat } \\
\text { Palm kernel meal (expeller) } \\
\text { Corn gluten feed } \\
\text { Extracted rapeseed meal } \\
\text { Extracted sunflower meal } \\
\text { Molasses } \\
\text { Linseed meal (expeller) } \\
\text { Peanut meal } \\
\text { Soybean meal } \\
\text { Vegetable oil } \\
\text { Mineral and vitamins }^{1}\end{array}$ & $\begin{array}{r}30.0 \\
15.0 \\
14.0 \\
11.0 \\
9.0 \\
5.0 \\
5.0 \\
5.0 \\
2.0 \\
3.0 \\
2.5\end{array}$ \\
\hline $\begin{array}{l}\text { Chemical component } \\
\text { Oven DM, \% } \\
\text { Ash } \\
\text { Acid hydrolysis ether extract } \\
\text { CP } \\
\text { NDF } \\
\text { ADF } \\
\text { Starch } \\
\text { Water-soluble carbohydrates }\end{array}$ & $\begin{array}{l}\text { Concentration } \\
85.6 \\
8.3 \\
4.9 \\
23.4 \\
29.5 \\
15.6 \\
24.3 \\
4.3\end{array}$ \\
\hline $\begin{array}{l}\text { Fatty acids, \% of DM } \\
\text { C12:0 } \\
\text { C14:0 } \\
\text { C16:0 } \\
\text { C18:0 } \\
\text { C18:1 } \\
\text { C18:2 } \\
\text { C18:3 } \\
\text { Total fatty acids }\end{array}$ & $\begin{array}{l}0.46 \\
0.16 \\
0.52 \\
0.10 \\
0.90 \\
0.95 \\
0.22 \\
3.42\end{array}$ \\
\hline
\end{tabular}

${ }^{1}$ Premix supplied (on a concentrate DM basis): 11,600 IU of vitamin $\mathrm{A} / \mathrm{kg}, 2300 \mathrm{IU}$ of vitamin D3/ kg, $29 \mathrm{IU}$ of vitamin $\mathrm{E} / \mathrm{kg}, 35 \mathrm{mg} / \mathrm{kg}$ of $\mathrm{Cu}, 140 \mathrm{mg} / \mathrm{kg}$ of $\mathrm{Mn}, 0.46 \mathrm{mg} / \mathrm{kg}$ of Se, and $14 \mathrm{mg} / \mathrm{kg}$ of $\mathrm{Zn}$.

Fresh grass silage was offered each morning, and the DM content was determined thrice weekly. Individual daily feed intake, milk yield, and milk composition were measured daily throughout the experimental period. Meal criteria were derived from automated records of the time intervals between successive visits to roughage feeders by individual cows using the model of Tolkamp et al. (1998). The cows were weighed and conditionscored ( 0 to 5 scale [Mulvany, 1977]) at the start of the trial and on the final day of each period.

\section{Sample Collection}

Silage samples were taken three times each week and composited into a single sample per period for chemical analysis. A sample of the concentrate was taken each period and composited into a single sample for the whole experiment. Milk samples were collected twice daily (a.m. and p.m.) on a weekly basis and analyzed for fat, protein, and lactose content by an infrared milk analyzer (Milkoscan 605; Foss Electric, Hillerød, Denmark). Additional milk samples were collected for fatty acid analyses twice daily at the end of each period.
These were stored at $-20^{\circ} \mathrm{C}$ without preservative, prior to freeze-drying and compositing of a.m. and p.m. samples for fatty acid analysis.

Blood samples were taken from the jugular vein into evacuated tubes containing lithium heparin (Vacutainer; Becton Dickinson Inc., Franklin Lakes, NJ) on two occasions in the last week of each period: $2 \mathrm{~h}$ after the a.m. milking and $2 \mathrm{~h}$ before the p.m. milking. Blood was held on ice, and spun at $1700 \times g$ for $25 \mathrm{~min}$ at $4^{\circ} \mathrm{C}$ to separate plasma, which was decanted and stored at $-20^{\circ} \mathrm{C}$ until analysis.

Grab samples of feces were also taken twice daily from the rectum of each cow at $1100 \mathrm{~h}$ and $1500 \mathrm{~h}$ on two consecutive days and stored in plastic containers at $-20^{\circ} \mathrm{C}$. Fecal samples were freeze-dried, composited, and milled (Christy-Norris mill with a 1-mm screen). Subsequently, the internal marker (acid insoluble ash) content was determined and used to estimate in vivo apparent digestibility (MAFF, 1986).

\section{Chemical Analysis}

Oven DM, total ash, and ether extract content of the silages and concentrate were determined according to Ministry of Agriculture, Fisheries and Food (1986). The total nitrogen in the silages and concentrates were respectively determined in fresh and freeze-dried samples milled to pass through a 1-mm screen using a Leco FP $428 \mathrm{~N}$ analyzer. Crude protein content was calculated by multiplying the total nitrogen content by a factor of 6.25. Starch, NDF, and ADF were determined on freezedried samples milled to pass through a 1-mm screen. The starch content was determined using the acid hydrolysis procedure of Faithfull (1990), and the cell wall contents were determined using the methods of Van Soest et al. (1991). Ammonia and water-soluble carbohydrate contents and fermentation products were determined from the juice extracted from the forages with a Motorq 20 (SP Tools, Cannock, U.K.) silage press. The water-soluble carbohydrate concentration was analyzed using the Anthrone reaction rate assay (MAFF, 1986), and the ammonia content was measured using a segmented flow analyzer ([Method Sheet S41-00803 November 83/1] Chemlab Instruments Ltd., Essex, UK). The acid-insoluble ash content of the feces was determined according to Ministry of Agriculture, Fisheries and Food (1986). The HPLC method described by Salawu et al. (1999) was used to determine the volatile fatty acid, lactic acid, ethanol, and formic acid concentrations of the silages. All results of feed analysis and DMI are quoted on a $100^{\circ} \mathrm{C}$ oven, DM basis.

Fatty acids in feeds and in milk were determined by gas chromatography as fatty acid methyl esters, which were prepared using the one-step extraction and meth- 
Table 2. Chemical analysis (\% of DM, unless stated otherwise) of pea-wheat bi-crops and grass silages.

\begin{tabular}{lccccc}
\hline & \multicolumn{5}{c}{ Forage ${ }^{1}$} \\
\cline { 2 - 5 } Measurement & HP1 & HP2 & LP1 & LP2 & GS \\
\hline pH & 4.40 & 4.30 & 4.00 & 4.20 & 4.00 \\
Oven-DM, \% & 22.7 & 25.1 & 22.3 & 25.9 & 22.6 \\
Ash & 7.2 & 7.9 & 7.2 & 7.4 & 7.1 \\
Ether extract & 2.9 & 2.2 & 2.1 & 1.8 & 3.1 \\
CP & 18.4 & 18.7 & 16.5 & 16.6 & 15.0 \\
Ammonia-N, \% of total-N & 11.2 & 13.4 & 11.3 & 12.8 & 8.4 \\
Water-soluble carbohydrates & 0.85 & 0.58 & 1.06 & 0.63 & 1.59 \\
Starch & 12.9 & 17.3 & 12.7 & 17.8 & 57.9 \\
NDF & 52.4 & 54.5 & 52.7 & 57.5 & 35.8 \\
ADF & 39.9 & 41.1 & 40.3 & 39.7 & 0.14 \\
ADIN & 0.15 & 0.17 & 0.14 & 2.02 & 7.39 \\
Lactic acid & 4.16 & 5.06 & 2.70 & 0.00 & 0.05 \\
Formic acid & 0.57 & 0.03 & 0.07 & 3.80 & 0.95 \\
Acetic acid & 3.33 & 4.65 & 4.62 & 0.81 & 0.10 \\
Propionic acid & 0.22 & 0.46 & 0.87 & 0.15 & 0.06 \\
Butyric acid & 0.05 & 0.05 & 0.09 & 0.70 & 0.43 \\
Ethanol & 1.19 & 1.02 & 1.06 & & \\
Fatty acids, \% of DM & & & & 0.20 & 0.23 \\
C16:0 & 0.24 & 0.23 & 0.23 & 0.23 & 0.19 \\
C18:2 & 0.21 & 0.23 & 0.18 & 0.14 & 0.47 \\
C18:3 & 0.29 & 0.17 & 0.26 & 0.73 & 1.05 \\
Total fatty acids & 0.89 & 0.82 & 0.81 &
\end{tabular}

${ }^{1} \mathrm{HP} 1$ = high-pea, cut 1; HP2 = high-pea, Cut 2; LP1 = low-pea, Cut 1; LP2 = low-pea, Cut 2. GS = grass silage.

ylation procedure of Sukhija and Palmquist (1988). Plasma glucose (kit no. 16-UV), albumin (kit no. 621$3 \mathrm{P}$ ), and total protein (kit no. 541-2) concentrations were determined using Sigma test kits (Sigma-Aldrich Company Ltd., Poole, UK) and a Cobas-Mira S analyzer (Roche Diagnostics Ltd., Lewes, East Sussex, UK). Plasma urea (kit no. 66), and BHBA (kit no. 310A) (BOHB) concentration were also determined using Sigma kits, but with an FP900 Discrete Analyzer (Labsystems Oy, Helsinki, Finland).

\section{Statistical Analysis}

Statistical analysis was conducted using results from the final week of each experimental period. Data were analyzed using the residual maximum likelihood directive within the Genstat statistical package (Genstat 5, Lawes Agricultural Trust, 1995). Dietary treatments were used as the "fixed" model, with "period" and "cow" as the "random" model. Covariate measurements were included in the model as appropriate (DMI, milk yield, and milk composition).

\section{RESULTS}

\section{Chemical Composition of the Feeds}

Salawu et al. (2002) discussed the yields and chemical composition of the pre-ensiled bi-crops. The chemical composition of the concentrate and silages are presented in Tables 1 and 2 , respectively. In comparison with the GS, the bi-crop silages had less acidic $\mathrm{pH}$ values, higher concentrations of starch, $\mathrm{CP}$ and ammonia, and lower concentrations of NDF. There were similar, moderate, concentrations of fermentation acids in all silages, though the pea-wheat bi-crop silages had lower concentrations of lactic acid and higher concentrations of acetic and propionic acids, particularly the LP bicrop silages.

The grass silage had a similar DM concentration to the Cut 1 bi-crop silage, whereas the DM concentration of the Cut 2 bi-crop silage was higher. The $\mathrm{CP}$ content of the bi-crop silages reflected their pea contents, with higher concentrations for the HP bi-crop silages; ammonia $\mathrm{N}$ content in the bi-crop silages was higher at Cut 2 than at Cut 1 . The NDF content of the bi-crop silages increased with maturity, and the increase was more pronounced in the LP bi-crop silages.

\section{Feed Intake and Diet Digestibility}

The results of analysis of forage feeding behavior, including intake rates, the total number of visits to feeders and the number of meals per day, defined according to the model of Tolkamp et al. (1998), are presented in Table 3. The cows fed the bi-crop silages had longer visit durations $(P<0.001)$ and they consumed more meals $(P<0.05)$ and visited the feed bunk more frequently. Consequently, bi-crop intakes were higher than the corresponding grass silage intakes (Table 4). In fact, the total DMI of the cows fed the bi-crop silages 
Table 3. Forage intake (kg DM/d) and meal patterns of dairy cows fed different pea-wheat bi-crops or grass silage.

\begin{tabular}{lrrrrrrrc}
\hline & \multicolumn{7}{c}{ Diet $^{1}$} \\
\cline { 2 - 8 } & HP1 & \multicolumn{1}{c}{ HP2 } & \multicolumn{1}{c}{ LP1 } & LP2 & GS6 & GS9 & SED $^{2}$ & Sig. $^{3}$ \\
\hline Forage DMI & 10.21 & 11.02 & 10.89 & 11.34 & 8.82 & 8.65 & 0.64 & $* *$ \\
Forage NDF intake & 5.35 & 5.98 & 5.76 & 6.54 & 5.04 & 4.95 & 0.35 & $* *$ \\
Forage ADF intake & 3.71 & 3.79 & 3.75 & 3.69 & 3.32 & 3.33 & 0.03 & $* *$ \\
Forage CP intake & 1.88 & 2.06 & 1.79 & 1.88 & 1.34 & 1.31 & 0.11 & $* *$ \\
Total DMI & 15.36 & 16.16 & 16.02 & 16.46 & 13.97 & 16.38 & 0.64 & $* *$ \\
Total NDF intake & 6.86 & 7.50 & 7.27 & 8.05 & 6.56 & 7.23 & 0.35 & $* *$ \\
Total ADF intake & 4.48 & 4.57 & 4.53 & 4.46 & 4.10 & 4.50 & 0.03 & $* *$ \\
Total CP intake & 3.09 & 3.27 & 2.99 & 3.08 & 2.54 & 3.09 & 0.15 & $* *$ \\
Meal patterns & & & & & & & & \\
$\quad$ Number of visits/d & 43.5 & 58.0 & 43.2 & 44.1 & 37.6 & 38.7 & 9.5 & NS \\
Visit duration, min/d & 248 & 237 & 250 & 263 & 216 & 207 & 11.2 & $* *$ \\
Forage intake rate, g DM/min & 42.2 & 49.1 & 44.5 & 44.1 & 43.0 & 43.4 & 4.5 & NS \\
Number of meals/d & 14.7 & 13.1 & 12.6 & 12.9 & 8.7 & 10.1 & 1.9 & $*$ \\
\hline
\end{tabular}

${ }^{1} \mathrm{HP} 1$ = high-pea, Cut 1; HP2 = high-pea, Cut 2; LP1 = low-pea, Cut 1; LP2 = low-pea Cut 2; GS6 = grass silage plus $6 \mathrm{~kg} / \mathrm{d}$ concentrates; GS9 = grass silage plus $9 \mathrm{~kg} / \mathrm{d}$ concentrates.

${ }^{2}$ Standard error of the difference.

${ }^{3}$ Significance.

$* P<0.05$.

$* * P<0.001$.

was similar to that of cows fed the GS9 diet. The ADF intake was consistently lowest in cows fed the GS6 diet, but CP intake was highest in cows fed the HP2 diet. The DMI was generally lower than the value $(19.8 \mathrm{~kg} /$ d) recommended for Holstein cows at this stage of lactation (NRC, 2001, Equation 1-2). Among bi-crop silages, DMI was lowest in diet HP1, and DM digestibility (Ta- ble 4) was greatest in cows fed the Cut 1 bi-crop diets, irrespective of pea-to-wheat ratio.

\section{Animal State}

There were no dietary effects on BCS or BW change. The BCS averaged 2.2 on the 0 -to-5 scale of Mulvany

Table 4. DMI (kg/d), DM digestibility (\%), milk yield (kg/d), and milk composition of dairy cows fed different pea-wheat bi-crops or grass silage.

\begin{tabular}{lcccccccc}
\hline & \multicolumn{7}{c}{ Diet $^{1}$} \\
\cline { 2 - 9 } Measurement & HP1 & HP2 & LP1 & LP2 & GS6 & GS9 & SED $^{2}$ & Sig. $^{3}$ \\
\hline Total DMI, kg/d & 15.4 & 16.3 & 16.1 & 16.5 & 13.7 & 16.3 & 0.5 & $* * *$ \\
DM digestibility, g/kg & 633 & 531 & 650 & 593 & 576 & 569 & 34 & $* * *$ \\
Digestible DMI, kg/d & 9.7 & 8.6 & 10.4 & 9.7 & 8.1 & 9.5 & 0.6 & $* * *$ \\
Milk yield, kg/d & 21.9 & 23.4 & 21.8 & 22.4 & 20.8 & 23.7 & 0.5 & $* * *$ \\
4\% FCM yield, kg/d & 26.3 & 27.1 & 25.8 & 26.2 & 26.5 & 29.6 & 0.9 & $* * *$ \\
Milk fat, \% & 4.82 & 4.66 & 4.79 & 4.71 & 5.14 & 5.02 & 0.16 & $*$ \\
Milk protein, \% & 3.04 & 3.04 & 3.07 & 3.10 & 3.06 & 3.17 & 0.03 & $* *$ \\
Milk lactose, \% & 4.71 & 4.70 & 4.72 & 4.74 & 4.67 & 4.66 & 0.03 & NS \\
Milk fat, g/d & 1050 & 1085 & 1030 & 1047 & 1061 & 1184 & 36 & $* * *$ \\
Milk protein, g/d & 665 & 709 & 664 & 689 & 632 & 748 & 17 & $* * *$ \\
Milk lactose, g/d & 1030 & 1102 & 1027 & 1061 & 970 & 1102 & 25 & $* * *$ \\
Milk-N/feed-N, \% & 21.3 & 21.6 & 21.6 & 22.0 & 24.9 & 23.2 & 1.0 & $* *$ \\
\hline
\end{tabular}

${ }^{1} \mathrm{HP} 1$ = high-pea, Cut 1; HP2 = high-pea, Cut 2; LP1 = low-pea, Cut 1; LP2 = low-pea, Cut 2; GS6 = grass silage plus $6 \mathrm{~kg} / \mathrm{d}$ concentrates; GS9 = grass silage plus $9 \mathrm{~kg} / \mathrm{d}$ concentrates.

${ }^{2}$ Standard error of the difference.

${ }^{3}$ Significance.

$* P<0.05$.

$* * P<0.01$.

$* * * P<0.001$. 
(1977) across the experiment, and BW change was $-0.21,0.68,0.05,0.50,0.85$, and $1.04 \mathrm{~kg} / \mathrm{d}$ for HP1, HP2, LP1, LP2, GS6, and GS9, respectively (SED = 0.68 ; not significant).

\section{Milk Production and Composition}

Milk yields were only moderate for cows at this stage of lactation, although milk fat concentrations were generally very high (Table 4 ). Milk yield increased (3 kg/ d) due to supplying the additional $3 \mathrm{~kg} / \mathrm{d}$ of the concentrate to cows fed the GS9 diet. Milk yields from cows fed the Cut 1 bi-crop diets were between those for cows fed the GS diets, whereas milk production from cows fed the Cut 2 bi-crop diets approximated that for cows fed the GS9 diet. The bi-crop diets depressed milk-fat concentration, relative to the GS diets but did not affect milk lactose concentration. Milk protein concentration was, however, higher for cows fed GS9 than for cows fed the other silages. Furthermore, feeding GS9 increased the yield of fat, protein, and lactose relative to the other treatments. Compared to GS6, feeding the bicrop silages resulted in comparable yields of milk fat, protein and lactose. The efficiency of conversion of feed $\mathrm{N}$ into milk $\mathrm{N}$ was consistently higher in cows fed grass silage.

Dietary treatment affected the proportions of the milk fatty acids, with the exception of C14:1, anteisoC15:0 and anteisoC17:0 (Table 5). The concentration of short- and medium-chain fatty acids (C6:0 to C14:0) were all higher for cows fed GS9 than for those fed the other treatments. Compared to the grass silage, the bicrop silages tended to lead to lower concentrations of C18:1 and similar or higher concentrations of trans vaccenic acid, conjugated linoleic acid, C18:2 and C18:3.

\section{Plasma Metabolites}

Plasma concentrations of protein, albumin, glucose and BHBA were not influenced by treatment (Table 6 ), though cows fed the bi-crop silages tended to have greater BHBA concentrations and lower total protein concentrations than those fed the GS diets. Plasma urea concentrations were higher $(P<0.001)$ for the bi-crop treatments than for the GS treatments. The highest plasma urea concentration was found in cows fed the HP2 treatment, and the lowest was in cows fed the GS6 treatment.

\section{DISCUSSION}

\section{Forage Composition}

The GS was of moderate quality, with relatively high NDF, moderate CP, and low water-soluble carbohy- drate and ammonia $\mathrm{N}$ concentrations. One of the objectives for feeding legume-cereal bi-crop silages to ruminants is to supply starch and protein, allowing minimal feeding of purchased concentrates. The bi-crop silages contained up to $18 \%$ starch (for Cut 2 ) and 16.5 to $18.7 \%$ CP. However, they also contained high concentrations of ammonia, indicating the occurrence of considerable proteolysis during ensiling, despite the use of the inoculant. This observation confirms the difficulties associated with conserving heterogenous forages (Kristensen, 1992). Nevertheless, the bi-crop silages had been adequately fermented, as evidenced by their low $\mathrm{pH}$ values and their concentrations of lactic acid plus acetic acid providing around $8 \%$ of DM. The slightly less acidic $\mathrm{pH}$ of the HP bi-crop silages may have been due to the buffering effect of the peas (Cussen et al., 1995). A noticeable characteristic of the fermentation of the bicrop silages was a shift towards the production of more acetate, particularly in the LP bi-crop silages. This shift is typical of silages low in water-soluble carbohydrates (Davies et al., 1998). In the present study, however, the inoculant additive that was used contained the heterofermentative lactic acid bacteria L. buchneri, which can ferment soluble sugar, as well as convert lactic acid to acetic acid (Elferink et al., 2001).

\section{Animal State}

In this experiment it was interesting that $\mathrm{BW}$ gain was highest for the mature bi-crop silages (LP2 and HP2) and the grass silage-based diets (GS6 and GS9). These diets were the least digestible (Table 4); hence, the observed BW gains are probably due to gut fill.

\section{Feed Intake and Diet Digestibility}

The diets used in this experiment had a much lower (mean $=35 \%$ of dietary DM) concentrate proportion than in the study reported by Tolkamp et al. ([1998] $58 \%$ of dietary DM). It seems likely that the high forage proportion in our diets explains the $40 \%$ higher number of visits, $60 \%$ increase in time spent at feeders, and doubling of the number of meals compared with the earlier study. The rate of intake of forage DM was only one-third of the rate of intake of DM from the TMR used by Tolkamp et al. (1998).

The cows readily accepted all diets, and were no adverse effects on cow health were observed. The higher intakes of bi-crop silages in comparison with grass silage were associated with an increased number of visits to feeders, an increase in the time spent at feeders, and more meals each day. Further studies are required to understand the interrelationships between intake, fermentation, and passage from the rumen in order to 
Table 5. Fatty acid composition (\% of total fatty acids) of milk from dairy cows fed different pea-wheat bicrops or grass silage supplemented with concentrates.

\begin{tabular}{|c|c|c|c|c|c|c|c|c|}
\hline \multirow[b]{2}{*}{ Measurement } & \multicolumn{8}{|c|}{ Diet $^{1}$} \\
\hline & HP1 & HP2 & LP1 & LP2 & GS6 & GS9 & $\mathrm{SED}^{2}$ & Sig. ${ }^{3}$ \\
\hline $\mathrm{C}_{6: 0}$ & 2.90 & 3.04 & 2.96 & 2.89 & 3.05 & 3.23 & 0.07 & $* * *$ \\
\hline $\mathrm{C}_{8: 0}$ & 1.79 & 1.84 & 1.90 & 1.77 & 1.92 & 2.09 & 0.06 & $* * *$ \\
\hline $\mathrm{C}_{10: 0}$ & 3.15 & 3.27 & 3.42 & 3.12 & 3.27 & 3.75 & 0.09 & $* * *$ \\
\hline $\mathrm{C}_{12: 0}$ & 4.21 & 4.30 & 4.47 & 4.21 & 4.22 & 5.22 & 0.10 & $* * *$ \\
\hline $\mathrm{C}_{14: 0}$ & 12.7 & 12.8 & 12.9 & 12.7 & 12.5 & 13.5 & 0.2 & $* * *$ \\
\hline $\mathrm{C}_{14: 1}$ & 1.09 & 1.09 & 1.09 & 1.10 & 1.08 & 1.14 & 0.04 & NS \\
\hline $\mathrm{C}_{15: 0}$ & 1.28 & 1.25 & 1.14 & 1.05 & 1.23 & 1.13 & 0.04 & $* * *$ \\
\hline iso $\mathrm{C}_{15: 0}$ & 0.24 & 0.26 & 0.25 & 0.24 & 0.29 & 0.28 & 0.01 & $* * *$ \\
\hline anteiso $\mathrm{C}_{15: 0}$ & 0.51 & 0.51 & 0.52 & 0.50 & 0.51 & 0.50 & 0.02 & NS \\
\hline $\mathrm{C}_{16: 0}$ & 39.5 & 38.7 & 38.2 & 39.6 & 35.1 & 33.6 & 0.7 & $* * *$ \\
\hline $\mathrm{C}_{16: 1}$ & 1.82 & 1.73 & 1.88 & 1.86 & 1.83 & 1.67 & 0.07 & ** \\
\hline $\mathrm{C}_{17: 0}$ & 0.53 & 0.55 & 0.57 & 0.51 & 0.53 & 0.44 & 0.03 & $* * *$ \\
\hline $\mathrm{C}_{17: 1}$ & 0.20 & 0.21 & 0.22 & 0.18 & 0.21 & 0.16 & 0.01 & $* * *$ \\
\hline iso $\mathrm{C}_{17: 0}$ & 0.34 & 0.38 & 0.37 & 0.33 & 0.40 & 0.36 & 0.02 & * \\
\hline anteiso $\mathrm{C}_{17: 0}$ & 0.40 & 0.40 & 0.40 & 0.38 & 0.38 & 0.37 & 0.02 & NS \\
\hline $\mathrm{C}_{18: 0}$ & 9.34 & 9.60 & 9.23 & 9.19 & 11.2 & 11.1 & 0.3 & $* * *$ \\
\hline $\mathrm{C}_{18: 1}$ & 16.6 & 16.4 & 17.0 & 16.8 & 19.0 & 18.2 & 0.5 & $* * *$ \\
\hline TVA $^{4}$ & 1.26 & 1.21 & 1.28 & 1.24 & 1.25 & 1.26 & 0.08 & NS \\
\hline CLA $^{5}$ & 0.41 & 0.37 & 0.41 & 0.39 & 0.39 & 0.37 & 0.03 & NS \\
\hline $\mathrm{C}_{18: 2}$ & 1.18 & 1.33 & 1.23 & 1.33 & 1.10 & 1.19 & 0.05 & **** \\
\hline $\mathrm{C}_{18: 3}$ & 0.35 & 0.32 & 0.32 & 0.26 & 0.35 & 0.33 & 0.02 & **** \\
\hline $\mathrm{C}_{20: 0}$ & 0.19 & 0.32 & 0.19 & 0.26 & 0.22 & 0.19 & 0.01 & **** \\
\hline $\mathrm{C}_{15: 0}$ :anteiso $\mathrm{C}_{15: 0}$ (ratio) & 2.56 & 2.47 & 2.19 & 2.16 & 2.39 & 2.26 & 0.10 & $* * *$ \\
\hline
\end{tabular}

${ }^{1} \mathrm{HP} 1$ = high-pea, Cut 1; HP2 = high-pea, Cut 2; LP1 = low-pea, Cut 1; LP2 = low-pea, Cut 2; GS6 = grass silage plus $6 \mathrm{~kg} / \mathrm{d}$ concentrates; GS9 = grass silage plus $9 \mathrm{~kg} / \mathrm{d}$ concentrates.

${ }^{2}$ Standard error of the difference.

${ }^{3}$ Significance.

${ }^{4}$ TVA $=$ Trans-vaccenic acid.

${ }^{5} \mathrm{CLA}=$ Conjugated linolenic acid.

$* P<0.05$.

$* * P<0.01$.

$* * * P<0.001$.

understand these effects and determine the cause of increased DMI with pea-wheat bi-crop silages. Parallel studies showed that pea-wheat bi-crop silages tended to have lower rates of DM degradation, assessed using nylon bags (Adesogan, Salawu, and Dewhurst, unpublished data). However, it is also known that legumes break down into smaller particles in the mouth and rumen at a faster rate than grasses (Waghorn et al., 1989; Dewhurst et al., 2000a). The higher frequency of feeding of the bi-crop silages may indicate increased passage rates from the rumen, as has been observed previously with legume (Hoffman et al., 1998; De-

Table 6. Blood metabolite concentrations of dairy cows fed different pea-wheat bi-crops or grass silages supplemented with concentrates.

\begin{tabular}{lcccccccc}
\hline & \multicolumn{7}{c}{ Diet $^{1}$} \\
\cline { 2 - 9 } Measurement & HP1 & HP2 & LP1 & LP2 & GS6 & GS9 & SED $^{2}$ & Sig. $^{3}$ \\
\hline Total protein, g/L & 73.5 & 71.5 & 72.4 & 71.7 & 73.5 & 76.5 & 1.8 & NS \\
Albumin, g/L & 40.0 & 39.2 & 39.4 & 39.2 & 39.4 & 39.6 & 0.8 & NS \\
Urea, mmol/L & 7.92 & 8.52 & 7.97 & 7.72 & 6.70 & 6.76 & 0.32 & $*$ \\
Glucose, mmol/L & 3.6 & 3.5 & 3.4 & 3.4 & 3.4 & 3.4 & 0.1 & NS \\
BHBA, mmol/L & 0.73 & 0.73 & 0.71 & 0.74 & 0.57 & 0.67 & 0.09 & NS \\
\hline
\end{tabular}

${ }^{1} \mathrm{HP} 1$ = high-pea, Cut 1; HP2 = high-pea, Cut 2; LP1 = low-pea, Cut 1; LP2 = low-pea, Cut 2; GS6 = grass silage plus $6 \mathrm{~kg} / \mathrm{d}$ concentrates; GS9 = grass silage plus $9 \mathrm{~kg} / \mathrm{d}$ concentrates.

${ }^{2}$ Standard error of the difference.

${ }^{3}$ Significance.

$* P<0.001$. 
whurst et al., 2000a) and mixed-forage diets (Phipps et al., 1995; O'Mara et al., 1998). Since NDF digestibility was lower in the GS than in the bi-crops (Adesogan et al., 2002), the enhanced bi-crop intake may reflect their relatively high starch and protein contents, which contrasts with the nutrient imbalance that is common with GS (Van Soest, 1994). Higher intakes of bi-crop silages than grass silage were also reported for sheep fed the same forages (Adesogan et al., 2002).

Earlier studies have identified problems when using acid-insoluble-ash as an internal marker to estimate digestibilities with legume-based diets (alfalfa). However, the fact that different studies have reported both under- and overestimations (Penning and Johnson, 1983; Sunvold and Cochran, 1991) suggests a more general problem with the technique. Nevertheless, the moderate digestibility values obtained with the technique in this study agree with results from total collection digestibility trials in sheep fed the same forages (Adesogan et al., 2002).

\section{Milk Yield and Composition}

The increased milk yield and milk protein concentration that resulted from the GS diet with the higher concentrate allocation demonstrates that the cows were responsive to additions of dietary protein and energy. When similar levels of concentrate were fed, higher milk yields were obtained by feeding bi-crops instead of feeding grass silage (GS6). This is partly attributable to the higher CP intakes and digestible DM intakes (Tables 3 and 4) that occurred when the bi-crops were fed. In other studies, low milk protein concentrations have been related to inadequate RUP supply (Wright et al., 1998). This does not explain the lower RUP supply of the bi-crop diets relative to that from the GS9 diet because the RUP supply from the bi-crop silages was higher $(P<0.05)$ than that from the grass silage (Adesogan, Salawu, and Dewhurst, unpublished data). A more pertinent explanation may be lower ruminal microbial protein production in the bi-crop diets resulting from asynchronous supply of readily fermentable energy and RDP. This suggestion is supported by the relatively high plasma urea concentrations found in cows fed the bi-crop treatments.

The generally high concentration of milk fat observed may have been caused by the low concentrate concentrations in the diets and the low supply of polyunsaturated fatty acids with these diets, resulting in lower concentrations of trans fatty acids, which cause milk fat depression (Bauman and Griinari, 2001). The tendency for lower milk fat concentrations in cows fed legumes is in agreement with Hoffman et al. (1998). The lower milk fat concentration of cows fed bi-crop silages may have been because cows fed GS diets mobilized more body fat than those fed bi-crop diets due to their lower feed intakes. Mobilization of body fat is correlated positively with milk fat concentration (Holter et al., 1990).

The concentration of $\alpha$-linolenic acid (C18:3) in milk was generally very low (Table 5). This partly reflects the effect of dilution within a greater concentration of total fatty acids, and lower concentrations of precursor (C18:3) in the diet (Table 5). The low concentrations of polyunsaturated fatty acids in the pea-wheat bi-crop were matched by unusually low concentrations in the GS, which reflects the nadir of fatty acid concentrations in grasses that occurs in June under our conditions (Dewhurst et al., 2001). The concentrations of the microbially-derived odd-chain fatty acids within total fatty acids were also low (Dewhurst et al., 2000b), and this might also be explained by dilution within greater concentrations of even-chain fatty acids. The proportion of anteisoC15:0 was particularly low, an observation that has previously been associated with a shortage of readily fermentable carbohydrates in the diet (Dewhurst et al., 2000b) and relatively low concentrations of liquid-associated bacteria in the rumen (Lee et al., 1999). The high milk fat concentrations and low polyunsaturated fatty acid in all the diets suggest considerable potential for the use of fat supplements to counter these effects.

Increased N-use efficiency was not observed with peawheat bi-crop silages (Table 4). The efficiency of conversion of feed-N to milk-N was similar $($ mean $=21.7 \%)$ for all pea-wheat treatments. It was not unexpected that N-use efficiency was higher (24.9\%) when the same amount of concentrates was offered with grass silage (GS6), because $\mathrm{N}$ intake was lower. However, N-use efficiency was also higher in grass silage when $\mathrm{N}$ intake was approximately the same, because of the feeding of additional concentrates (GS9;23.2\%).

\section{Plasma Metabolites}

The only blood constituent that was influenced by diet was blood urea, and this reflects the lower N-use efficiency noted above. Relative to those from grass silage diets, the higher blood urea concentration of cows fed bi-crop silages is attributable to their higher RDP supply (Adesogan, Salawu, and Dewhurst, unpublished data). This was excessive relative to the rumen degradable starch supplied, which was also higher than that supplied from the grass silage (Adesogan, Salawu, and Dewhurst, unpublished data). Other authors have also related high blood urea to high supply of RDP (Cody et al., 1990; O'Mara et al., 2000). One anticipated advantage of feeding bi-crop silages of cereals and legumes is 
the improvement in the efficiency of nutrient utilization due to a possible synchronous supply of readily fermentable energy and protein in the rumen. The high concentration of blood urea, however, suggests that in this case, the readily fermentable energy supply from the bi-crop silages was inadequate or that the RDP content was excessive. Similarly, inefficient protein utilization was observed in sheep fed the same bi-crop silages (Adesogan et al., 2002). Further studies must address this problem, for example, by increasing the nonstructural carbohydrate concentration of the supplemental concentrate, using higher cutting heights to increase the fermentability of the bi-crop, or by using different varieties of cereal and pea.

Although the plasma BHBA concentrations were lower than levels that denote the occurrence of subclinical ketosis ( $>1400 \mu \mathrm{mol} / /$ [Geishauser et al., 2000]), the low plasma glucose levels indicate that the energy supplied from the feeding of moderate concentrate amounts and moderate quality forages was not optimal.

\section{CONCLUSIONS}

The pea-wheat bi-crop silages contained higher CP and starch concentrations and resulted in higher forage intakes than the grass silage. Compared with cows fed GS6, those fed the bi-crop diets gave between 1 and 2.6 $\mathrm{kg}$ milk yield that contained higher concentrations of omega-3 polyunsaturated fatty acids, lower milk fat concentrations, and similar milk protein concentrations. Therefore, at a similar, low amount of concentrate supplementation, feeding the bi-crop silages can result in better animal performance than feeding moderate quality grass silage. These deductions, along with the high-yield potential and absence of $\mathrm{N}$ fertilizer requirement for bi-crop silages, suggest that they may be more appropriate for low input and organic farming systems than moderate-quality grass silage. Future work should examine how the bi-crop silages compare to higher quality forages.

Cows fed the GS9 diet gave more milk and higher milk protein concentrations than all the bi-crop silages except the HP2 bi-crop diet. Therefore, the concentratesparing effect of the bi-crop silages that were evaluated seemed marginal, and as such they may have a limited role as an alternative feed in high input systems. This problem may be related to inadequate supply of fermentable carbohydrate from the bi-crop silages, as is evident from high blood urea concentrations. Consequently, future studies are required on milk production from bi-crop silages with higher energy densities, such as those with shorter pea varieties or higher grain to straw ratios.
The absence of large differences between the bi-crop silages in their effects on feed intake, milk production and composition, and blood metabolite concentrations shows that bi-crop silages have a wide harvest window as well as a wide range of pea-to-wheat ratio over which the nutritive value remains similar. This is in accord with findings of Adesogan et al. (2001a), who demonstrated that with preconserved bi-crop forages, increasing the proportion of peas above $40 \%$ increased the CP concentration but only marginally increased the overall forage quality.

\section{ACKNOWLEDGMENTS}

The authors gratefully acknowledge the funding of this project by the UK Milk Development Council and the assistance of the farm and technical staff of the Institute of Rural Studies, University of Wales, Aberystwyth and the Institute of Grassland and Environmental Research, Aberystwyth for their assistance with various aspects of the study. Thanks are also due to Dr. Charles Staples for reviewing the manuscript.

\section{REFERENCES}

Adesogan, A. T., M. B. Salawu, and E. R. Deaville. 2002. The effect on voluntary feed intake, in vivo digestibility and nitrogen balance in sheep of feeding grass silage or pea-wheat intercrops differing in pea to wheat ratio and maturity. Anim. Feed Sci. Technol. 96:161-273.

Bauman, D. E., and J. M. Griinari. 2001. Regulation and nutritional manipulation of milk fat: Low-fat milk syndrome. Livest. Prod. Sci. 70:15-29.

Cody, R. F., J. J. Murphy, and D. J. Morgan. 1990. Effect of supplementary crude protein concentration and degradability in grass silage based diets on performance of dairy cows, and digestibility and abomasal nitrogen flow in sheep. Anim. Prod. 51:235-244.

Cussen, R. F., R. J. Merry, A. P. Williams, and J. K. S. Tweed. 1995. The effect of additives on the ensilage of forage of differing perennial ryegrass and white clover content. Grass For. Sci. 50:249-258.

Davies, D. R., R. J. Merry, A. P. Williams, E. L. Bakewell, D. K. Leemans, and J. K. S. Tweed. 1998. Proteolysis during ensilage of forages varying in soluble sugar content. J. Dairy Sci. 81:444-453.

Davis, A. W., and W. B. Hall. 1969. Cyclical change-over designs. Biometrika 56:283-293.

Dewhurst, R. J., A. M. Mitton, N. W. Offer, and C. Thomas. 1996. Effects of the composition of grass silages on milk production and nitrogen utilization by dairy cows. Anim. Sci. 62:25-34.

Dewhurst, R. J., D. W. R. Davies, W. J. Fisher, J. Bertilsson, and R. J. Wilkins. 2000a. Effects of legume silages on the quality and particle size distribution of rumen contents in Holstein-Friesian cows. Page 1 in Proc. Br. Soc. Anim. Sci. Ann. Mtg., Scarborough, UK.

Dewhurst, R. J., D. R. Davies, and R. J. Merry. 2000b. Microbial protein supply from the rumen. Anim. Feed Sci. Technol. 85:1-21.

Dewhurst, R. J., N. D. Scollan, S. J. Youell, J. K. S. Tweed, and M. O. Humphreys. 2001. Influence of species, cutting date and cutting interval on the fatty acid composition of grasses. Grass For. Sci. $56: 68-74$.

Elferink, S. J. W. H. O., J. Krooneman, J. C. Gottschal, S. F. Spoelstra, F. Faber, and F. Driehuis. 2001. Anaerobic conversion of lactic acid to acetic acid and 1,2-propanediol by Lactobacillus buchneri. Appl. Environ. Microbiol. 67:125-132. 
Faithfull, N. T. 1990. Acid hydrolysis prior to automatic analysis for starch. J. Sci. Food Agric. 50:419-421.

Geishauser, T., K. Leslie, J. Tenhag, and A. Bashiri. 2000. Evaluation of eight cow-side ketone tests in milk for detection of subclinical ketosis in dairy cows. J. Dairy Sci. 83:296-299.

Hoffman, P. C., D. K. Combs, and M. D. Casler. 1998. Performance of lactating dairy cows fed alfalfa silage or perennial ryegrass silage. J. Dairy Sci. 81:162-168.

Holter, J. B., M. J. Slotnick, H. H. Hayes, C. K. Bozak, W. E. Urban, Jr., and M. L. McGilliard. 1990. Effect of prepartum dietary energy on condition score, postpartum energy, nitrogen partitions and lactation production responses. J. Dairy Sci. 73:3502-3511.

Koehler, L. H. 1952. Differentiation of carbohydrate by Anthrone reaction rate and colour intensity. Anal. Chem. 24:1576-1579.

Kristensen, V. F. 1992. The production and feeding of whole-crop cereals and legumes in Denmark. Pages 21-38 in Whole-crop Cereals. 2nd ed. B. A. Stark and J. M. Wilkinson, ed. Chalcombe Publications, Canterbury, United Kingdom.

Lee, S. S., M. B. Chang, N. D. Scollan, R. J. Merry, M. S. Dhanoa, P. J. Hobbs, V. J. Theobald, W. J. Maeng, and R. J. Dewhurst. 1999. The fatty acid composition of solid- and liquid-associated rumen bacteria isolated from cows. Page 30 in Proc. Br. Soc. Anim. Sci. Ann. Mtg., Scarborough, UK.

Ministry of Agriculture, Fisheries and Food (MAFF). 1986. Analysis of Agricultural Materials. Reference book 427. 3rd ed. Her Majesty's Stationary Office, London, United Kingdom.

Mulvany, P. 1977. Dairy cow condition scoring. National Institute for Research in Dairying Paper No. 4468.

Mustafa, A. F., D. A. Christensen, and J. J. McKinnon. 2000. Effects of pea, barley, and alfalfa silage on ruminal nutrient degradability and performance of dairy cows. J. Dairy Sci. 83:2859-2865.

National Research Council (NRC). 2001. Nutrient requirements of dairy cattle. 7th Rev. Ed. National Academy Press, Washington, D.C.

O'Mara, F. P., J. J. Murphy, and M. Rath. 2000. The effect of concentrate supplements differing in ruminal protein degradability on milk production and blood metabolite concentrations of dairy cows grazing perennial ryegrass pasture. Livest. Prod. Sci. 64:183-191.

O’Mara, F. P., J. J. Murphy, J. J Fitzgerald, and M. Rath. 1998. The effect on milk production of replacing grass silage with maize silage in the diet of dairy cows. Livest. Prod. Sci. 55:79-87.

Penning, P. D., and P. H. Johnson. 1983. The use of internal markers to estimate herbage digestibility and intake. 1. Potentially indigestible cellulose and acid insoluble ash. J. Agric. Sci. (Camb.) 100:127-131.
Phipps, R. H., J. D. Sutton, and B. A. Jones. 1995. Forage mixtures for dairy-cows: The effect on dry-matter intake and milk-production of incorporating either fermented or urea-treated wheat, brewers grains, fodder beet or maize silage into on grass-silage. Anim. Sci. 61:491-496.

Salawu, M. B., and A. T. Adesogan. 1999. Aerobic stability of peawheat bi-crop silages treated with different additives. Pages 282 283 in Proc. 12th Int. Silage Conf., Uppsala, Sweden.

Salawu, M. B., T. Acamovic, C. S. Stewart, T. Hvelplund, and M. R. Weisbjerg. 1999. The use of tannins as silage additives: Effects on silage composition and mobile bag disappearance of dry matter and protein. Anim. Feed Sci. Technol. 82:243-259.

Salawu, M. B., and A. T. Adesogan, N. Weston, and S. P. Williams. 2001a. Dry matter yield and nutritive value of pea-wheat bicrops differing in maturity at harvest, pea to wheat ratio and pea variety. Anim. Feed Sci. Technol. (In press).

Salawu, M. B., E. H. Warren, and A. T. Adesogan. 2001b. Fermentation characteristics, aerobic stability and ruminal degradation of ensiled pea wheat bi-crop forages treated with two microbial inoculants, formic acid or quebracho tannins. J. Sci. Food Agric. 81:1263-1268.

Sukhija, P. S., and D. L. Palmquist. 1988. Rapid method for the determination of total fatty acid content and composition of feedingstuffs and fecaes. J. Agric. and Food Chem. 36:1202-1206.

Sunvold, G. D., and R. C. Cochran. 1991. Evaluation of acid detergent lignin, alkaline peroxide lignin, acid insoluble ash, and indigestible acid detergent fiber as internal markers for prediction of alfalfa, bromegrass, and prairie hay digestibility by beef steers. J. Anim. Sci. 69:4951-4955.

Tolkamp, B. J., D. J. Allcroft, E. J. Austin, B. L. Nielsen, and I. Kyriazakis. 1998. Satiety splits feeding behaviour into bouts. J. Theor. Biol. 194:235-250.

Van Soest, P. J. 1994. Nutritional Ecology of the Ruminant. Cornell University Press, Ithaca, NY.

Van Soest, P. J., J. D. Robertson, and B. A. Lewis. 1991. Methods for dietary fiber, neutral detergent fiber and non-starch polysaccharide in relation to animal nutrition. J. Dairy Sci. 74:35833597.

Waghorn, G. C., I. D. Shelton, and V. J. Thomas. 1989. Particle breakdown and rumen digestion of fresh ryegrass and lucerne fed to cows during a restricted feeding period. Br. J. Nutr. 61:409-423.

Wright, T. C., S. Moscardini, P. H. Luimes, P. Susmel, and B. W. McBride. 1998. Effects of rumen undegradable protein and feed intake on nitrogen balance and milk protein production in dairy cows. J. Dairy Sci. 81:784-793.

Zadoks, J. C., T. T. Cheng, and C. F. Konzak. 1974. A decimal code for the growth stages of cereals. Weed Res. 14:415-421. 